\title{
The Hundred Most Cited Articles in Bariatric Surgery
}

\author{
Suhaib S. Ahmad • Sufian S. Ahmad • Sandro Kohl • \\ Sami Ahmad • Ahmed R. Ahmed
}

Published online: 27 February 2015

(C) Springer Science+Business Media New York 2014

\begin{abstract}
Background Many studies quantitatively analyzing scientific papers have appeared in the last 2 years. Citation analysis is a commonly used bibliometric method. In spite of some limitations, it remains a good measure of the impact an article has on a specific field, specialty, or a journal. The aim of this study was to analyze the qualities and characteristics of the 100 most cited articles in the field of bariatric surgery.

Methods The Thomson Reuters Web of Knowledge was used to list all bariatric surgery-related articles (BSRA) published from 1945 to 2014. The top 100 most cited BSRA in 354 surgical and high impact general journals were selected for further analysis.

Results Most of the articles were published in the 2000s (60\%). The top 100 most cited were published in 17 of the 354 journals. Leading countries were USA followed by Canada and Australia. Most of the articles published (76\%) were clinical experience articles. The most common level of evidence was IV (42\%).

Conclusions Many of the milestone papers in bariatric surgery have been included in this bibliometric study. A huge increase in research activity during the last decade is clearly visible in the field. It is apparent that the number of citations of
\end{abstract}

S. S. Ahmad

Buckingham Institute for Translational Medicine, University of Buckingham, Buckingham, UK

S. S. Ahmad $(\varangle) \cdot$ S. Kohl

Department of Orthopaedic Surgery and Traumatology, Inselspital, University of Bern, Bern, Switzerland

e-mail: sufiansamy@gmail.com

S. Ahmad

Bariatric Surgery, Jordan Hospital, Amman, Jordan

A. R. Ahmed

Department of Bariatric and Metabolic Surgery, Imperial College

London, London, UK an article is not related to its level of evidence; a fact that is increasingly being emphasized in surgical research.

Keywords Bibliometric study · Top 100 most cited articles . Obesity $\cdot$ Bariatric surgery $\cdot$ Citation classics

\section{Introduction}

Academic writing and publishing in surgery are a way of sharing a valuable experience with the rest of the surgical and nonsurgical communities. Sir Francis Ernest Rutherford once said "I have to publish my present work as rapidly as possible in order to keep in the race." In addition to the notoriety of having a paper published, the number of citations a paper has become a way of determining its value.

A citation is a reference of a published or an unpublished source. The number of citations a scientific paper gains reflects its impact on the specialty and draws attention to the originality of authors $[1,2]$. Besides the credit given to an author when publishing in a prestigious journal, the number of acquired citations is also regarded as an award for the author [3].

Bibliometric analysis is a tool for quantitatively analyzing the characteristics and scholarly impact of citation classics. Garfield published the first bibliometric study for the JAMA in 1987 entitled: "Top 100 best-cited articles ever published in JAMA." Since then, more articles are appearing not only in general but also increasingly in specialty journals $[1,4,5]$.

Articles with high impact are constantly being published; therefore, bibliometric articles are ones with a limited life span, and this in turn is determined by the activity of publishing in a specific field. Unfortunately, leading-edge discovery papers are being superseded by new knowledge papers as new knowledge papers integrate and correct previous knowledge. 
This in turn causes older papers to lose their spotlight with time.

The Institute for Scientific Information (ISI) offers bibliographic database services and specializes in citation analysis and indexing, a field pioneered by Garfield. It contains accurate information about papers published since 1945. This database can be accessed through the ISI web of knowledge, which is an academic citation analysis, citation indexing, and search service $[3,4,6]$.

Bariatric surgery has expanded vastly since its beginnings in the 1950s. The advent of laparoscopic surgery has catalyzed this growth. Alongside this, research in the field was initiated and subspecialty journals were launched (Surgery for Obesity and Related Diseases (SOARD) founded in 2005 and Obesity Surgery founded in 1991) [7].

The aim of this bibliometric study is to report on the characteristics of the most cited papers in the field of bariatric surgery.

\section{Methods}

The Thomson Reuters Web of Knowledge was used to list all bariatric surgery-related articles published from 1945 to 2014, in 354 surgical and general medical journals in a categorized way. The search terms "Obesity" and "Bariatric surgery" were used.

It was assumed that the least cited article in the list would possess 120 or more citations; therefore, all articles in each journal with less than 120 citations were excluded to decrease the effort of having to scan through all articles. Articles were pooled and two independent investigators reviewed titles and abstracts based on the following inclusion criteria: basic laboratory or animal research related to any aspect of bariatric surgery; clinical therapeutic, prognostic, diagnostic, epidemiological studies, or expert opinions with primary focus on one or more bariatric surgical procedures. Disagreement between authors on article eligibility was considered an exclusion criterium.

The search was conducted during the first week of September 2014. All of the selected bariatric surgery research articles from all of the 354 journals were sorted according to their citation number and listed in descending order. Both lists produced by the two investigators were sent to a third investigator to make sure there was no difference between the two lists. All articles were ranked based on their citation number, and the 100th rank was the last to be included in the study.

Each article was analyzed for the following: publication date, journal name, first and senior authors, year of publication, geographic origin, total number of citations, citation density (total citations/article age), research type (clinical review, clinical experience, and basic science (human or animal studies)), and level of evidence (I-V for clinical articles according to the guidance of the Journal of Bone and Joint Surgery) (Table 1) [8]. Any differences in results obtained by the two investigators were discussed (Fig. 1).

WinStat version 2012.181 was utilized for statistical analysis. The Shapiro-Wilk test was used to test the distribution of the data, the Mann-Kendall's trend test was used to test timedependant trends, Spearman rang was used to test for correlations, data were subsequently presented as mean \pm standard deviation, and one-way analysis of variance (ANOVA) was utilized to test the difference between normally distributed data. A $P$ value of less than 0.05 was considered as statistically significant.

\section{Results}

The 354 surgical and general medical journals covered a wide range of different topics from general clinical to subspecialty and basic research.

The total number of citations ranged from 157 to 1527 for articles published between 1963 and 2009. More than two third of articles were published after 1997. Most articles were published in the 2000s $(n=60)$ followed by 1990s $(n=21)$, 1970s $(n=11), 1980 \mathrm{~s}(n=4)$, and 1960s $(n=4)$. The years with the highest number of high citation published articles were $2002(n=9), 2003(n=9)$, and $2004(n=9)$. The overall mean number of citations was 334 . The mean number of citations was also the highest in articles published in the 2000s (366) followed by the 1960s (341), the 1980s (315), the 1990s (308), and the 1970s (210) (Fig. 2). The Mann-Kendall's trend test showed an increasing trend between the citation density and the time $P=1.071 \mathrm{E}-10$ (Fig. 3). Spearman rank showed no correlation between time and citations $r=0.126 P=0.105$ and showed positive correlation between time and citation density $r=0.650 P=1.241 \mathrm{E}-13$. The Shapiro-Wilk test showed normal distribution of the data.

The 100 most cited articles were published in 18 of the total 354 surgical and general medical journals, 13 American, one Canadian, two British, and one German. All 17 journals were within the top 50 percentile of the category regarding impact factor.

All of the articles originated from 12 countries, led by USA ( $n=64)$ followed by Canada $(n=7)$, Australia $(n=7)$, France $(n=5)$, Belgium $(n=4)$, Italy $(n=3)$, Sweden $(n=3)$, UK $(n=$ $2)$, Switzerland $(n=2)$, Spain $(n=1)$, Germany $(n=1)$, and Austria ( $n=1)$ (Fig. 4). All articles originating from UK were published in one American journal, namely the Annals of Surgery (Ann Surg). Of the 64 articles originating from the USA, ten were published in a Canadian journal (Obesity Surgery), 52 in American journals (New England Journal of Medicine, American Journal of Medicine, American Journal of Surgery, Annals of Internal Medicine, Annals of Surgery, Archives of Internal Medicine, Archives of Surgery, Journal of 
Table 1 List of the 100 top-cited articles in bariatric surgery research

$\begin{array}{ll}\text { Rank Article Citations } & \end{array}$

(density)

1 Sjöström L, Lindroos AK, Peltonen M, Torgerson 1527 (153)

J, Bouchard C, Carlsson B, Dahlgren S, Larsson

B, Narbro K, Sjöström CD, Sullivan M, Wedel

H; Swedish Obese Subjects Study Scientific

Group. Lifestyle, diabetes, and cardiovascular risk factors 10 years after bariatric surgery. $\mathrm{N}$ Engl J Med. 2004 Dec 23;351(26):2683-93.

2 Sjöström L, Narbro K, Sjöström CD, Karason K,

Larsson B, Wedel H, Lystig T, Sullivan M,

Bouchard C, Carlsson B, Bengtsson C, Dahlgren

S, Gummesson A, Jacobson P, Karlsson J,

Lindroos AK, Lönroth H, Näslund I, Olbers T,

Stenlöf K, Torgerson J, Agren G, Carlsson LM;

Swedish Obese Subjects Study. Effects of

bariatric surgery on mortality in Swedish obese

subjects. N Engl J Med. 2007 Aug

23;357(8):741-52.

3 Cummings DE, Weigle DS, Frayo RS, Breen PA,

Ma MK, Dellinger EP, Purnell JQ. Plasma

ghrelin levels after diet-induced weight loss or

gastric bypass surgery. N Engl J Med. 2002 May 23;346(21):1623-30.

4 Ebbeling CB, Pawlak DB, Ludwig DS. Childhood 1098 (92)

obesity: public-health crisis, common sense cure. Lancet. 2002 Aug 10;360(9331):473-82.

5 Pories WJ, Swanson MS, MacDonald KG, Long

SB, Morris PG, Brown BM, Barakat HA, deRamon RA, Israel G, Dolezal JM. Who would have thought it? An operation proves to be the most effective therapy for adult-onset diabetes mellitus. Ann Surg. 1995 Sep;222(3):339-50; discussion 350-2.

6 Adams TD, Gress RE, Smith SC, Halverson RC, Simper SC, Rosamond WD, Lamonte MJ, Stroup AM, Hunt SC. Long-term mortality after gastric bypass surgery. N Engl J Med. 2007 Aug 23;357(8):753-61.

7 Schauer PR, Ikramuddin S, Gourash W, Ramanathan R, Luketich J. Outcomes after laparoscopic Roux-en-Y gastric bypass for morbid obesity. Ann Surg. 2000

Oct;232(4):515-29.

8 Buchwald H, Estok R, Fahrbach K, Banel D, Jensen MD, Pories WJ, Bantle JP, Sledge I. Weight and type 2 diabetes after bariatric surgery: systematic review and meta-analysis. Am J Med. 2009 Mar;122(3):248-256.e5. doi: 10.1016/j.amjmed.2008.09.041.

9 Maggard MA, Shugarman LR, Suttorp M, Maglione M, Sugerman HJ, Livingston EH, Nguyen NT, Li Z, Mojica WA, Hilton L, Rhodes S, Morton SC, Shekelle PG. Meta-analysis: surgical treatment of obesity. Ann Intern Med. 2005 Apr 5;142(7):547-59.

10 Christou NV, Sampa0lis JS, Liberman M, Look D, 578 (58) Auger S, McLean AP, MacLean LD. Surgery decreases long-term mortality, morbidity, and health care use in morbidly obese patients. Ann Surg. 2004 Sep;240(3):416-23; discussion 4234.0
Table 1 (continued)

Rank Article $\quad \begin{aligned} & \text { Citations } \\ & \text { (density) }\end{aligned}$

(density)

Grundy Sm, Barondess Ja, Bellegie, $\mathrm{Nj}$, Fromm $\mathrm{H}$, Greenway F, Halsted Ch, Huth Ej, Kumanyika Sk, Reisen E, Robinson Mk, Stevens J, Twomey Pl, Viederman M, Zipf W. Gastrointestinal surgery for severe obesity. 1991 DEC 15:115(12):956-61.

12 Nguyen NT, Goldman C, Rosenquist CJ, Arango A, Cole CJ, Lee SJ, Wolfe BM. Laparoscopic versus open gastric bypass: a randomized study of outcomes, quality of life, and costs. Ann Surg. 2001 Sep;234(3):279-89; discussion 289-91.

13 Schauer PR, Burguera B, Ikramuddin S, Cottam D, 529 (48) Gourash W, Hamad G, Eid GM, Mattar S, Ramanathan R, Barinas-Mitchel E, Rao RH, Kuller L, Kelley D. Effect of laparoscopic Rouxen $\mathrm{Y}$ gastric bypass on type 2 diabetes mellitus. Ann Surg. 2003 Oct;238(4):467-84; discussion 84-5.

14 Mason EE. Vertical banded gastroplasty for obesity. Arch Surg. 1982 May;117(5):701-6.

15 Rosenbaum M, Leibel RL, Hirsch J. Medical progress - Obesity. N Engl J Med. 1997AUG 7;337(6): 396-407

16 Payne JH, DeWind LT. Surgical treatment of obesity. Am J Surg. 1969 Aug;118(2):141-7.

17 Wittgrove AC, Clark GW. Laparoscopic gastric bypass, Roux-en-Y- 500 patients: technique and results, with 3-60 month follow-up. Obes Surg. 2000 Jun;10(3):233-9.

18 Mason EE, Ito C. Gastric bypass in obesity. Surg Clin North Am. 1967 Dec;47(6):1345-51.

19 Buchwald H, Williams SE. Bariatric surgery worldwide 2003. Obes Surg. 2004 Oct;14(9):1157-64.

20 le Roux CW, Aylwin SJ, Batterham RL, Borg CM, Coyle F, Prasad V, Shurey S, Ghatei MA, Patel AG, Bloom SR. Gut hormone profiles following bariatric surgery favor an anorectic state, facilitate weight loss, and improve metabolic parameters. Ann Surg. 2006 Jan;243(1):108-14.

21 Wittgrove AC, Clark GW, Tremblay LJ. Laparoscopic Gastric Bypass, Roux-en-Y: Preliminary Report of Five Cases. Obes Surg. 1994 Nov;4(4):353-357.

22 Donato KA, Pi-Sunyer FX, Becker DM, Bouchard 368 (23) C, Carleton RA, Colditz GA, Dietz WH, Foreyt JP, Garrison RJ, Grundy SM, Hansen BC, Higgins M, Hill JO, Howard BV, Kuczmarski RJ, Kumanyika S, Legako RD, Prewitt TE, Rocchini AP, Snetselaar LG, Weintraub M, Williamson DF, Wilson, GT, Brown CD, Ernst N, Hill DR, Horan MJ, Kiley JP, Obarzanck E, Hubbard VS, Schriger D, Chiquette E. Executive summary of the clinical guidelines on the identification, evaluation, and treatment of overweight and obesity in adults. Arch Intern Med. 1998 Sep 28;158(17):1855-67.

23 Sugerman HJ, Starkey JV, Birkenhauer R. A randomized prospective trial of gastric bypass versus vertical banded gastroplasty for morbid obesity and their effects on sweets versus non$504(16)$

$541(42)$

-


Table 1 (continued)

Rank Article
Citations

(density)

sweets eaters. Ann Surg. 1987 Jun;205(6):613-

24.

24 Rubino F, Forgione A, Cummings DE, Vix M,

$357(45)$

Gnuli D, Mingrone G, Castagneto M,

Marescaux J. The mechanism of diabetes control

after gastrointestinal bypass surgery reveals a

role of the proximal small intestine in the

pathophysiology of type 2 diabetes. Ann Surg.

2006 Nov;244(5):741-9.

25 Scopinaro N, Adami GF, Marinari GM, Gianetta E， 356 (22)

Traverso E, Friedman D, Camerini G, Baschieri

G, Simonelli A. Biliopancreatic diversion.

World J Surg. 1998 Sep;22(9):936-46.

26 Flum DR, Belle SH, King WC, Wahed AS, Berk P, 355 (71)

Chapman W, Pories W, Courcoulas A,

McCloskey C, Mitchell J, Patterson E, Pomp A,

Staten MA, Yanovski SZ, Thirlby R, Wolfe B.

Perioperative safety in the longitudinal

assessment of bariatric surgery. N Engl J Med. 2009 Jul 30;361(5):445-54.

27 Higa KD, Boone KB, Ho T. Complications of the

$332(24)$

laparoscopic Roux-en-Y gastric bypass: 1,040

patients-what have we learned?. Obes Surg.

2000 Dec;10(6):509-13.

28 Podnos YD, Jimenez JC, Wilson SE, Stevens CM, 330 (30)

Nguyen NT. Complications after laparoscopic

gastric bypass: a review of 3464 cases. Arch

Surg. 2003 Sep;138(9):957-61.

29 Marceau P, Hould FS, Simard S, Lebel S, Bourque 328 (21)

RA, Potvin M, Biron S. Biliopancreatic

diversion with duodenal switch. World J Surg.

1998 Sep;22(9):947-54.

30 Steinbrook R. Surgery for severe obesity. N Engl J 319 (32) Med. 2004 March 11;350(11):1075-79

31 Buchwald H, Oien DM. Metabolic/bariatric sur- 318 (64)

gery Worldwide 2008. Obes Surg. 2009

Dec;19(12):1605-11. doi: 10.1007/s11695-0090014-5.

32 Regan JP, Inabnet WB, Gagner M, Pomp A. Early 317 (29) experience with two-stage laparoscopic Roux-

en-Y gastric bypass as an alternative in the super-super obese patient. Obes Surg. 2003 Dec;13(6):861-4.

33 Hess DS, Hess DW. Biliopancreatic diversion with 310 (19) a duodenal switch. Obes Surg. 1998 Jun;8(3):267-82.

34 Rubino F, Marescaux J. Effect of duodenal-jejunal 309 (31) exclusion in a non-obese animal model of type 2 diabetes: a new perspective for an old disease. Ann Surg. 2004 Jan;239(1):1-11.

35 McTigue KM, Harris R, Hemphill B, Lux L, Sutton 307 (28) S, Bunton AJ, Lohr KN. Screening and interventions for obesity in adults: Summary of the evidence for the US Preventive Services Task Force. 2003 DEC 2:139(11):933-49.

36 DeMaria EJ, Sugerman HJ, Kellum JM, Meador JG, Wolfe LG. Results of 281 consecutive total laparoscopic Roux-en-Y gastric bypasses to treat morbid obesity. Ann Surg. 2002

May;235(5):640-5; discussion 645-7.
Table 1 (continued)

Rank Article

Citations

(density)

Chapman AE, Kiroff G, Game P, Foster B, O’Brien P, Ham J, Maddern GJ. Laparoscopic adjustable gastric banding in the treatment of obesity: a systematic literature review. Surgery. 2004 Mar;135(3):326-51.

38 Service GJ, Thompson GB, Service FJ, Andrews JC, Collazo-Clavell ML, Lloyd RV. Hyperinsulinemic hypoglycemia with nesidioblastosis after gastric-bypass surgery. $\mathrm{N}$ Engl J Med. 2005 Jul 21;353(3):249-54.

Drenick EJ, Simmons F, Murphy JF. Effect on hepatic morphology of treatment of obesity by fasting, reducing diets and small-bowel bypass. N Engl J Med. 1970 Apr 9;282(15):829-34.

40 Rubino F, Gagner M, Gentileschi P, Kini S, Fukuyama S, Feng J, Diamond E. The early effect of the Roux-en-Y gastric bypass on hormones involved in body weight regulation and glucose metabolism. Ann Surg. 2004 Aug;240(2):236-42.

41 Griffen WO Jr, Young VL, Stevenson CC. A prospective comparison of gastric and jejunoileal bypass procedures for morbid obesity. Ann Surg. 1977 Oct;186(4):500-9.

42 Flum DR, Dellinger EP. Impact of gastric bypass operation on survival: a population-based analysis. J Am Coll Surg. 2004 Oct;199(4):543-51.

43 Himpens J, Dapri G, Cadière GB. A prospective randomized study between laparoscopic gastric banding and laparoscopic isolated sleeve gastrectomy: results after 1 and 3 years. Obes Surg. 2006 Nov;16(11):1450-6.

Brolin RE, Kenler HA, Gorman JH, Cody RP. Long-limb gastric bypass in the superobese. A prospective randomized study. Ann Surg. 1992 Apr;215(4):387-95.

Payne Jh, Dewind Lt, Commons Rr. Metabolic observations in patients with jejunocolic shunts. Am J Surg. 1963 Aug;106:273-89.

Buchwald H, Estok R, Fahrbach K, Banel D, Sledge I. Trends in mortality in bariatric surgery: a systematic review and meta-analysis. Surgery. 2007 Oct;142(4):621-32; discussion 632-5.

47 Cottam D, Qureshi FG, Mattar SG, Sharma S, Holover S, Bonanomi G, Ramanathan R, Schauer P. Laparoscopic sleeve gastrectomy as an initial weight-loss procedure for high-risk patients with morbid obesity. Surg Endosc. 2006 Jun;20(6):859-63. Epub 2006 Apr 22.

O'Brien PE, Dixon JB, Laurie C, Skinner S, Proietto J, McNeil J, Strauss B, Marks S, Schachter L, Chapman L, Anderson M. Treatment of mild to moderate obesity with laparoscopic adjustable gastric banding or an intensive medical program: a randomized trial. Ann Intern Med. 2006 May 2;144(9):625-33.

Langer FB, Reza Hoda MA, Bohdjalian A, Felberbauer FX, Zacherl J, Wenzl E, Schindler K, Luger A, Ludvik B, Prager G. Sleeve gastrectomy and gastric banding: effects on 
Table 1 (continued)

Rank Article
Citations

(density)

plasma ghrelin levels. Obes Surg. 2005

Aug;15(7):1024-9.

50 O'Brien PE, Dixon JB, Brown W, Schachter LM,

Chapman L, Burn AJ, Dixon ME, Scheinkestel

C, Halket C, Sutherland LJ, Korin A, Baquie P.

The laparoscopic adjustable gastric band (Lap-

Band): a prospective study of medium-term

effects on weight, health and quality of life. Obes

Surg. 2002 Oct;12(5):652-60.

51 Wands JR, LaMont JT, Mann E, Isselbacher KJ.

Arthritis associated with intestinal-bypass

procedure for morbid obesity. Complement

activation and characterization of circulating

cryoproteins. N Engl J Med. 1976 Jan

15;294(3):121-4.

52 Hall JC, Watts JM, O'Brien PE, Dunstan RE, Walsh JF, Slavotinek AH, Elmslie RG. Gastric surgery for morbid obesity. The Adelaide Study. Ann Surg. 1990 Apr;211(4):419-27.

Sugerman HJ, Wolfe LG, Sica DA, Clore JN Diabetes and hypertension in severe obesity and effects of gastric bypass-induced weight loss. Ann Surg. 2003 Jun;237(6):751-6; discussion 757-8.

54 Mann Gv. Influence of obesity on health. N Engl J 229 (6) Med. 1974; 291(4):178-85

55 Sugerman HJ, Londrey GL, Kellum JM, Wolf L, 225 (13) Liszka T, Engle KM, Birkenhauer R, Starkey JV. Weight loss with vertical banded gastroplasty and Roux-Y gastric bypass for morbid obesity with selective versus random assignment. Am J Surg. 1989 Jan;157(1):93-102.

56 Scopinaro N, Gianetta E, Adami GF, Friedman D, 224 (9) Traverso E, Marinari GM, Cuneo S, Vitale B, Ballari F, Colombini M, Baschieri G, Bachi V. Biliopancreatic diversion for obesity at eighteen years. Surgery. 1996 Mar;119(3):261-8. 57 Mason EE, Ito C. Gastric bypass. Ann Surg. 1969224 (5)
Sep;170(3):329-39.

58 O'Brien PE, Brown WA, Smith A, McMurrick PJ, 221 (15) Stephens M. Prospective study of a laparoscopically placed, adjustable gastric band in the treatment of morbid obesity. Br J Surg. 1999 Jan;86(1):113-8.

59 Higa KD, Boone KB, Ho T, Davies OG. Laparoscopic Roux-en-Y gastric bypass for morbid obesity: technique and preliminary results of our first 400 patients. Arch Surg. 2000 Sep;135(9):1029-33; discussion 1033-4.

60 Ren CJ, Patterson E, Gagner M. Early results of laparoscopic biliopancreatic diversion with duodenal switch: a case series of 40 consecutive patients. Obes Surg. 2000 Dec;10(6):514-23; discussion 524.

61 Baltasar A, Serra C, Pérez N, Bou R, Bengochea M, Ferri L. Laparoscopic sleeve gastrectomy: a multi-purpose bariatric operation. Obes Surg. 2005 Sep;15(8):1124-8.

62 DeMaria EJ, Sugerman HJ, Meador JG, Doty JM, 213 (16)

Kellum JM, Wolfe L, Szucs RA, Turner MA.

High failure rate after laparoscopic adjustable
Table 1 (continued)

Rank Article Citations

(density)

silicone gastric banding for treatment of morbid obesity. Ann Surg. 2001 Jun;233(6):809-18.

63 Schauer P, Ikramuddin S, Hamad G, Gourash W. The learning curve for laparoscopic Roux-en-Y gastric bypass is 100 cases. Surg Endosc. 2003 Feb;17(2):212-5. Epub 2002 Dec 4.

64 le Roux CW, Welbourn R, Werling M, Osborne A, 212 (30) Kokkinos A, Laurenius A, Lönroth H, Fändriks L, Ghatei MA, Bloom SR, Olbers T. Gut hormones as mediators of appetite and weight loss after Roux-en-Y gastric bypass. Ann Surg. 2007 Nov;246(5):780-5.

65 Scopinaro N, Gianetta E, Civalleri D, Bonalumi U, 211 (6) Bachi V. Bilio-pancreatic bypass for obesity: II. Initial experience in man. Br J Surg. 1979 Sep;66(9):618-20.

66 Bloomberg RD, Fleishman A, Nalle JE, Herron DM, Kini S. Nutritional deficiencies following bariatric surgery: what have we learned? Obes Surg. 2005 Feb;15(2):145-54.

67 Chevallier JM, Zinzindohoué F, Douard R, Blanche JP, Berta JL, Altman JJ, Cugnenc PH. Complications after laparoscopic adjustable gastric banding for morbid obesity: experience with 1,000 patients over 7 years. Obes Surg. 2004 Mar; 14(3):407-14.

68 O'Brien PE, McPhail T, Chaston TB, Dixon JB. Systematic review of medium-term weight loss after bariatric operations. Obes Surg. 2006 Aug;16(8):1032-40.

69 Oria HE, Moorehead MK. Bariatric analysis and reporting outcome system (BAROS) Obes Surg. 1998 Oct;8(5):487-99.

70 Livingston EH, Huerta S, Arthur D, Lee S, De Shields S, Heber D. Male gender is a predictor of morbidity and age a predictor of mortality for patients undergoing gastric bypass surgery. Ann Surg. 2002 Nov;236(5):576-82.

71 Fobi MA, Lee H, Holness R, Cabinda D. Gastric bypass operation for obesity. World J Surg. 1998 Sep;22(9):925-35.

72 MacLean LD, Rhode BM, Nohr CW. Late outcome 201 (20) of isolated gastric bypass. Ann Surg. 2000 Apr;231(4):524-8.

73 MacLean LD, Rhode BM, Sampalis J, Forse RA. 199 (9) Results of the surgical treatment of obesity. Am J Surg. 1993 Jan;165(1):155-60; discussion 1602.

74 Moxley RT, Pozefsky T, Lockwood DH. Protein nutrition and liver disease after jejunoileal bypass for morbid obesity. N Engl J Med. 1974 Apr 25;290(17):921-6.

75 Peterli R, Wölnerhanssen B, Peters T, Devaux N, 196 (39) Kern B, Christoffel-Courtin C, Drewe J, von Flüe M, Beglinger C. Improvement in glucose metabolism after bariatric surgery: comparison of laparoscopic Roux-en-Y gastric bypass and laparoscopic sleeve gastrectomy: a prospective randomized trial. Ann Surg. 2009 Aug;250(2):234-41. doi: 10.1097/ SLA.0b013e3181ae32e3. 
Table 1 (continued)

Rank Article
Citations

(density)

76 Payne JH, DeWind L, Schwab CE, Kern WH. Surgical treatment of morbid obesity. Sixteen years of experience. Arch Surg. 1973 Apr;106(4):432-7.

77 Cadière GB, Himpens J, Germay O, Izizaw R, Degueldre M, Vandromme J, Capelluto E, Bruyns J. Feasibility of robotic laparoscopic surgery: 146 cases. World J Surg. 2001 Nov;25(11):1467-77.

78 Christou NV, Look D, Maclean LD. Weight gain after short- and long-limb gastric bypass in patients followed for longer than 10 years. Ann Surg. 2006 Nov;244(5):734-40.

Tice JA, Karliner L, Walsh J, Petersen AJ, Feldman MD. Gastric banding or bypass? A systematic review comparing the two most popular bariatric procedures. Am J Med. 2008 Oct;121(10):88593. doi: 10.1016/j.amjmed.2008.05.036.

80 MacLean LD, Rhode BM, Forse RA. Late results of vertical banded gastroplasty for morbid and super obesity. Surgery. 1990 Jan;107(1):20-7.

81 Belachew M, Belva PH, Desaive C. Long-term results of laparoscopic adjustable gastric banding for the treatment of morbid obesity. Obes Surg. 2002 Aug;12(4):564-8.

82 Alden JF. Gastric and jejunoileal bypass. A comparison in the treatment of morbid obesity. Arch Surg. 1977 Jul;112(7):799-806.

83 Capella JF, Capella RF. The weight reduction operation of choice: vertical banded gastroplasty or gastric bypass? Am J Surg. 1996 Jan;171(1):74-9.

84 Rubino F, Gagner M. Potential of surgery for curing type 2 diabetes mellitus. Ann Surg. 2002 Nov;236(5):554-9.

85 Weiner R, Blanco-Engert R, Weiner S, Matkowitz R, Schaefer L, Pomhoff I. Outcome after laparoscopic adjustable gastric banding - 8 years experience. Obes Surg. 2003 Jun;13(3):427-34.

86 Deitel M. Overweight and obesity worldwide now estimated to involve 1.7 billion people. Obes Surg. 2003 Jun;13(3):329-30.

87 Dixon JB, Dixon ME, O'Brien PE. Depression in association with severe obesity: changes with weight loss. Arch Intern Med. 2003 Sep 22;163(17):2058-65.

Belachew M, Legrand M, Vincent V, Lismonde M, 180 (11) Le Docte N, Deschamps V. Laparoscopic adjustable gastric banding. World J Surg. 1998 Sep;22(9):955-63.

89 Suter M, Calmes JM, Paroz A, Giusti V. A 10-year experience with laparoscopic gastric banding for morbid obesity: high long-term complication and failure rates. Obes Surg. 2006 Jul;16(7):829-35.

90 Brolin RE, LaMarca LB, Kenler HA, Cody RP. Malabsorptive gastric bypass in patients with superobesity. J Gastrointest Surg. 2002 MarApr;6(2):195-203; discussion 204-5.

91 Brolin RE, Robertson LB, Kenler HA, Cody RP. Weight loss and dietary intake after vertical
Table 1 (continued)

$\begin{array}{ll}\text { Rank Article } & \begin{array}{l}\text { Citations } \\ \text { (density) }\end{array}\end{array}$

196 (5) banded gastroplasty and Roux-en-Y gastric bypass. Ann Surg. 1994 Dec;220(6):782-90.

92 Sugerman HJ, Sugerman EL, DeMaria EJ, Kellum 174 (16) JM, Kennedy C, Mowery Y, Wolfe LG. Bariatric surgery for severely obese adolescents. J Gastrointest Surg. 2003 Jan;7(1):102-7; discussion 107-8.

93 Hickey MS, Pories WJ, MacDonald KG Jr, Cory $170(11)$ KA, Dohm GL, Swanson MS, Israel RG, Barakat HA, Considine RV, Caro JF, Houmard JA. A new paradigm for type 2 diabetes mellitus: could it be a disease of the foregut? Ann Surg. 1998 May;227(5):637-43; discussion 643-4.

94 Hocking MP, Duerson MC, O’Leary JP, Woodward 168 (5) ER. Jejunoileal bypass for morbid obesity. Late follow-up in 100 cases. N Engl J Med. $1983 \mathrm{Apr}$ 28;308(17):995-9.

95 Smith U, Hammersten J, Björntorp P, Kral JG. Regional differences and effect of weight reduction on human fat cell metabolism. Eur J Clin Invest. 1979 Oct;9(5):327-32.

96 Mason EE, Printen KJ, Hartford CE, Boyd WC. Optimizing results of gastric bypass. Ann Surg. 1975 Oct;182(4):405-14.

97 DeMaria EJ. Bariatric surgery for morbid obesity. N Engl J Med. 2007 May24;356(21):2176-2183

98 Ravussin E, Swinburn BA. Pathophysiology of obesity. Lancet. 1992 Aug 15;340(8816):404-8.

99 Shagrin JW, Frame B, Duncan H. Polyarthritis in obese patients with intestinal bypass. Ann Intern Med. 1971 Sep;75(3):377-80.

100 Buchwald H. Bariatric surgery for morbid obesity: 157 (17) Health implications for patients, health professionals and third-party payers. J Am Coll Surg. 2005 Apr;200(4):593-604.

The American College of Surgeons, Journal of Gastrointestinal Surgery, Surgical Clinics of North America, Surgical Endoscopy and Other Interventional Techniques, Surgery and World Journal of Surgery) and two in a British journal (Lancet). Of the seven articles originating from Canada, one was published in a Canadian journal namely Obesity Surgery and six in American journals (Surgery, World Journal of Surgery, Annals of Surgery, and American Journal of Surgery) (Table 2).

There were 18 recurring first authors and eight recurring senior authors (Table 3). Sugerman HJ had the highest number of first authorships. The total number of citations for his four articles is 993; all of his articles were clinical experience articles. Maclean LD has three first authorships and two senior authorships with a total number of citations of 1356 for his five clinical experience articles.

Of the 100 articles, 76 were clinical experience articles (surgery outcomes), 21 clinical review (review of the literature), and three dealt with basic science (experiment 
Fig. 1 Flowchart illustrating the process of allocation of articles

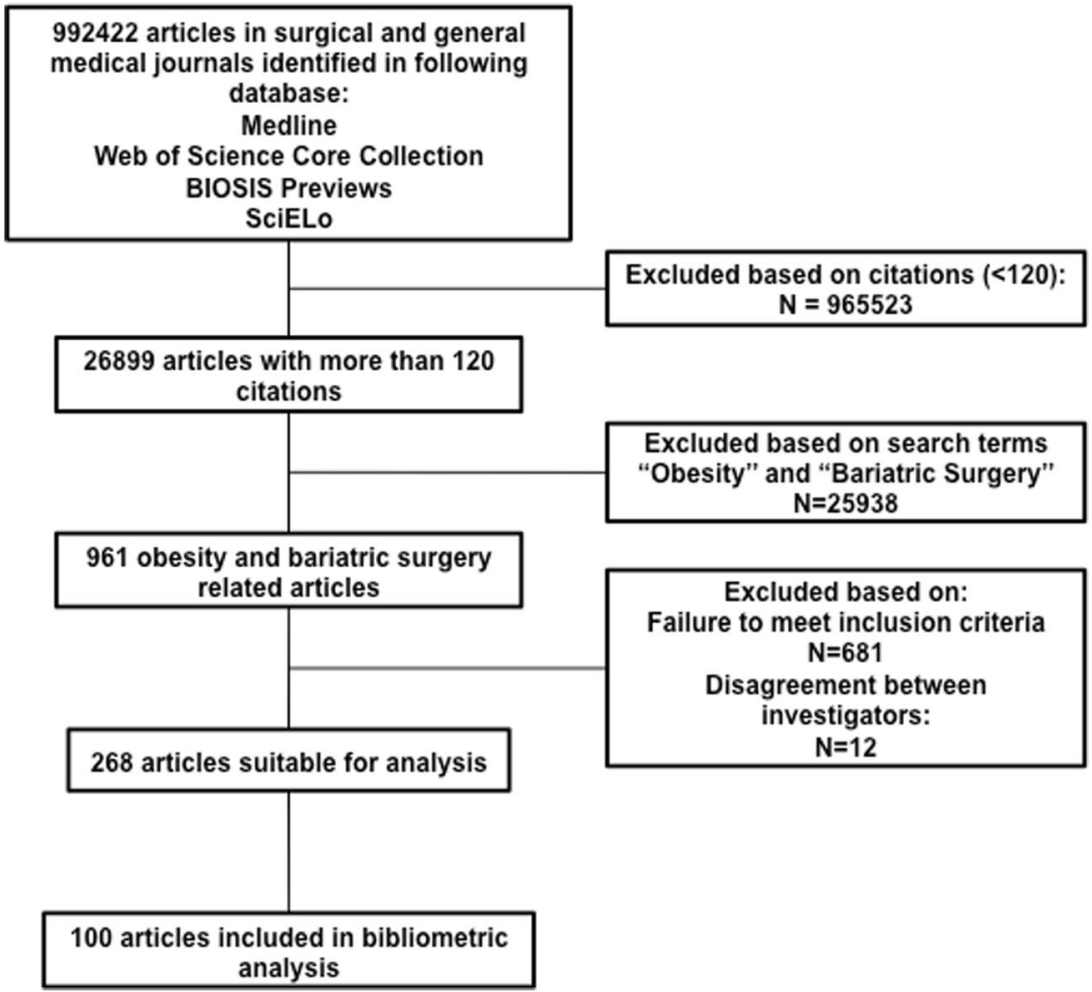

outcomes). Within the 100 articles, there were seven cohort studies, 18 systematic reviews, nine randomized controlled trials (RCTs), seven expert opinion, and 14 comparative studies. All of the articles were given a level of evidence (I-V).

Forty-two of the 100 articles had a level of evidence of IV with a mean citation per article of $289 \pm 795,37$ had a level of II with a mean citation of $393 \pm 1134$, nine had a level of I with a mean of $287 \pm 254$, seven had a level of $\mathrm{V}$ with a mean of $321 \pm 229$, and five had a level of III with a mean of $371 \pm 480$. One-way ANOVA showed no significant difference between citations per article in all of the level of evidences $(P=0.44)$ (Fig. 5).

\section{No. Of Articles per decade}

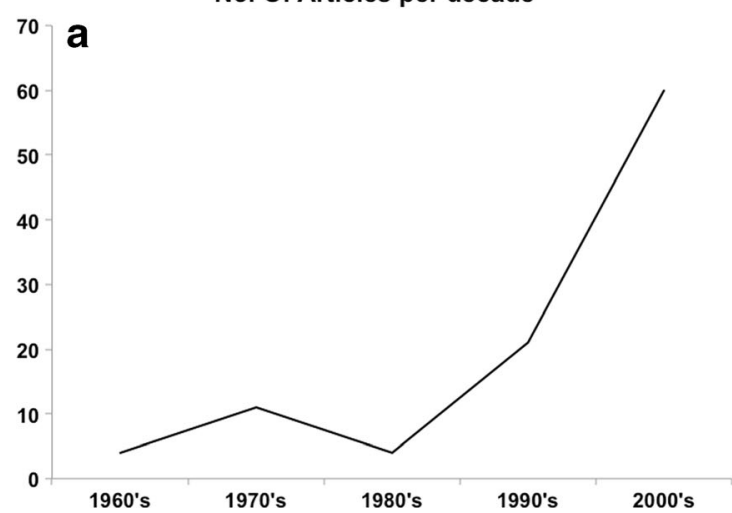

\section{Discussion}

The number of times an article is cited is a good way of measuring the impact this article has on a specific field or topic and in turn allows evaluation of the author and the journal [2]. It is important to note that the number of citations an article receives is a measure of its impact over a period of time not its quality, due to the fact that gathering citations is a time-dependent process. It is also important to note that new knowledge dominates in the field of research and this is supported by the fact that the frequency of citing decreases overtime; a phenomenon known as "obliteration by

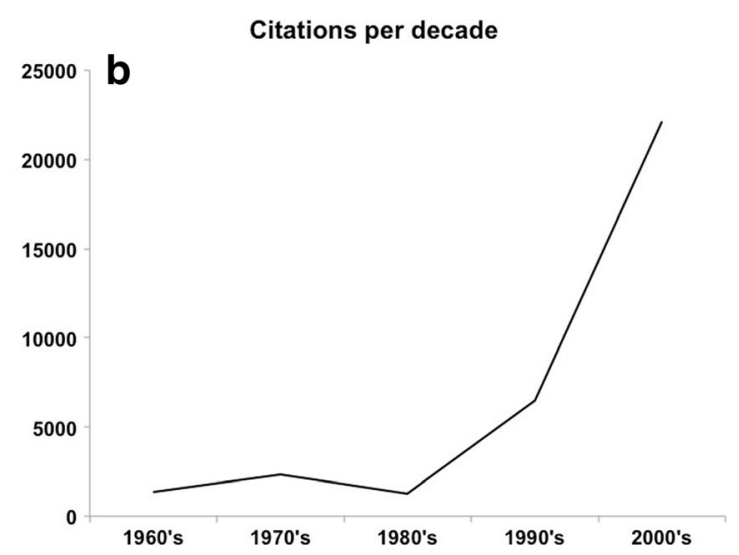

Fig. 2 a Total number of articles per decade. b Total number of citations per decade 
Citation Density

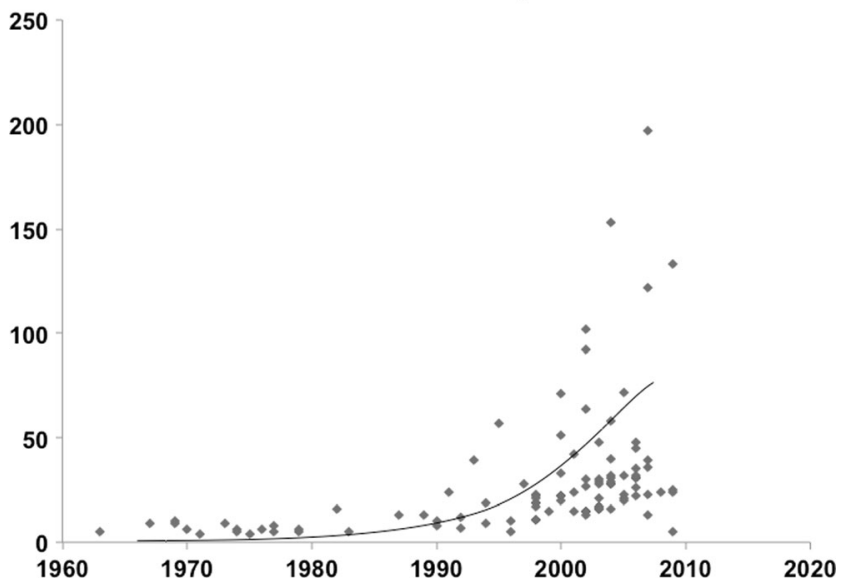

Fig. 3 Time-dependent citation density trend

incorporation" [4]. This has also been demonstrated in our analysis. Most of the top 100 cited articles were published in the $2000 \mathrm{~s}(60 \%)$, followed by articles published in the $1990 \mathrm{~s}$ (21\%), 1970s (11\%), 1980s (4\%), and 1960s (4\%). Bibliometric studies provide a reflection on the current state of an article; this can be supported by the fact that the older the article gets, the greater the time provided for it to be cited. Many important papers such as prospective randomized trials [9], a long-term follow-up study [10] and a paper on the effect of surgically induced weight loss on diseases [11], may have not made it into the list due to receiving too few citations. In
Table 2 Journal in which the top-cited 100 articles were published

\begin{tabular}{ll}
\hline Journal & No. of articles \\
\hline Annals of Surgery & 26 \\
Obesity Surgery & 20 \\
The New England Journal of Medicine & 14 \\
The American Journal of Surgery & 5 \\
Archives of Surgery & 5 \\
World Journal of Surgery & 5 \\
Annals of Internal Medicine & 5 \\
Surgery & 4 \\
British Journal of Surgery & 2 \\
Journal of Gastrointestinal Surgery & 2 \\
Surgical Endoscopy & 2 \\
Lancet & 2 \\
Archives of Internal Medicine & 2 \\
American Journal of Medicine & 2 \\
Journal of the American College of Surgeons & 2 \\
Surgical Clinics of North America & 1 \\
European Journal of Clinical Investigation & 1
\end{tabular}

spite of this, most ground breaking discoveries in the bariatric field were found within the top-cited list, such as the SOS study (Effects of bariatric surgery on mortality in Swedish obese subjects) by Sjöström [12] which received 1376
Fig. 4 Countries from which the 100 highest cited articles originated

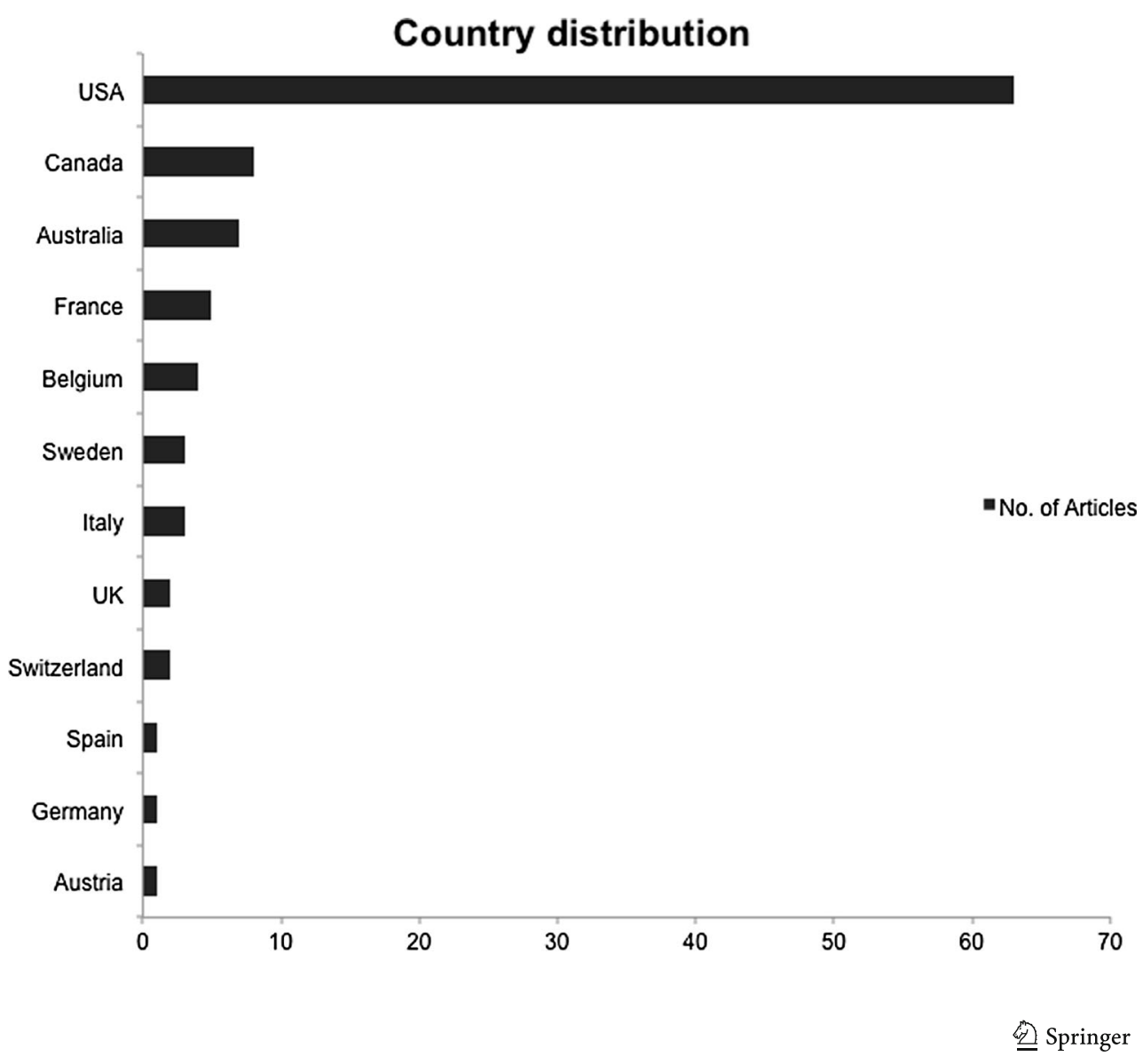


Table 3 List of first or senior authors with frequent articles within the top-cited list

\begin{tabular}{llll}
\hline Frequent first authors & No. of articles & Frequent last authors & No. of articles \\
\hline Sugerman HJ & 4 & Cody RP & 3 \\
Buchwald H & 4 & Bachi V & 2 \\
Mason EE & 4 & Forse RA & 2 \\
Rubino F & 4 & Gagner M & 2 \\
O’Brien PE & 4 & MacLean LD & 2 \\
MacLean LD & 3 & Marescaux J & 2 \\
DeMaria EJ & 3 & Mason EE & 2 \\
Payne JH & 3 & Wolfe LG & \\
Schauer PR & 3 & & \\
Scopinaro N & 3 & & \\
Brolin RE & 3 & & \\
Christou NV & 2 & & \\
Belachew M & 2 & & \\
le Roux CW & 2 & \\
Wittgrove AC & 2 & \\
Flum DR & 2 & \\
Sjöström L & 2 & & \\
Higa KD & 2 & & \\
\end{tabular}

citations up till now and was published in 2007 in The New England journal of medicine.

Bariatric surgery evolved more than six decades ago, but since then, many clinicians have dedicated themselves to explain the mechanisms of action of bariatric surgery. Based on our analysis, some prolific authors have often demonstrated a focus and lead in one of the three areas: clinical experience (Mason EE), basic research (Rubino F), and clinical review (Buchwald $\mathrm{H}$ ) [13].

The leading country relating the number of articles published was USA, and this can also be noticed in many other fields such as emergency medicine [14], urology [15], critical care medicine [16], orthopedics [5], general surgery [1], and sepsis research [17]. This is likely due to the fact that the US

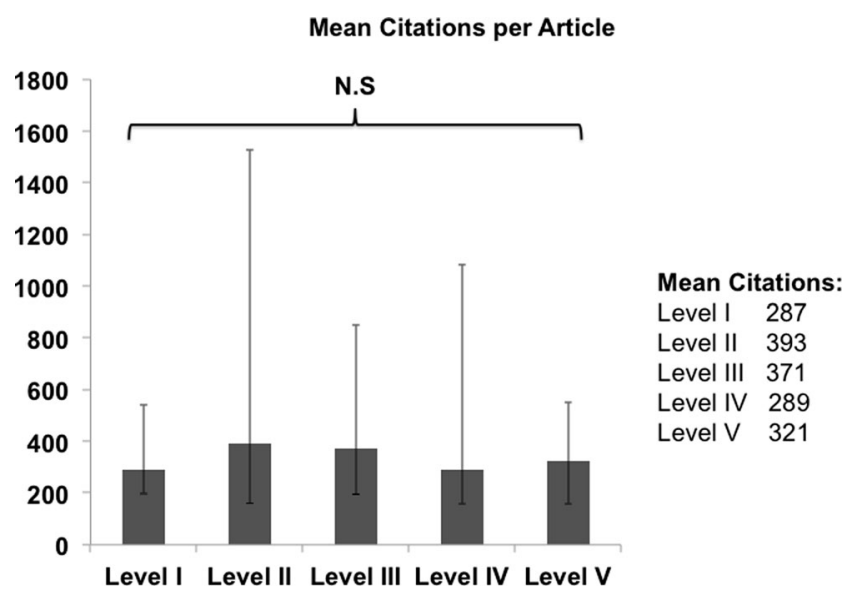

Fig. 5 Mean citation per article based on level of evidence. N.S not significant government was more advanced in the bariatric field historically due to the larger burden of obesity in the population and also due to the fact that it provides the largest budget for research. Some researchers have previously noted a weak correlation between the GDP per capita of a country and the research output [18].

Journals with high impact factor are attractive to authors. This in turn causes the authors preferentially to send their research papers to these journals [19-21]. All of the 100 articles were published in 18 journals, 13 of which are American, two British, two Canadian, and one German. In fact, 60 of the 100 articles were published in just three journals namely Annals of Surgery, Obesity Surgery, and The New England Journal of Medicine.

One outcome from our analysis was the low level of evidence (LOE) for the "Top 100 most cited articles." This has not previously been noted in other bibliometric studies [22-26]. Our results show that almost half (42\%) of the articles had a LOE of IV, and most these level IV articles with no control group. This leads us to a conclusion that innovative ideas initially published in a case series can still gain publicity and attention by the scientific community. However, it should also act as a warning signal for the bariatric surgery community that if we are to be taken seriously by the rest of the scientific community, then, we should make an effort to publish material of more evidence.

The study has some limitations. In this study, the minimum number of citations was 157 per article resulting in the exclusion of a number of more recent significant articles that may have not have made it into the list. Equally, some journals will 
not have made it into our list. An example being the specialty journal Surgery for Obesity and Related Disease (SOARD), since the article with the highest citation in SOARD was 139, which is attributed to the recent first-issue release, such issues can be addressed in further bibliometric updates.

\section{Conclusion}

Many studies quantitatively analyzing the scientific literature have been appearing during the past few years. These articles provide a source of great value for young investigators and seem to be cited rapidly after publication. Updates of bibliometric articles are necessary, due to their limited life span; updates are likely to identify trends in research patterns $[1,2,7]$.

This bibliometric study shows a huge rising academic interest in bariatric surgery, since the beginning of the last decade. Most of the top-cited papers were published in 17 of the top-ranking journals, mostly from the USA and UK, followed by Canada and Germany. Most of the articles were clinical experience (case series) articles. It can also be observed as now shown by several studies of this type in surgical research that level of evidence does not correlate with number of citations and that the majority of citation classics are of level IV evidence [27]. This should stimulate discussion within the bariatric surgical community.

Conflict of interest All authors declare no conflict of interest, and there was no external funding for this study.

\section{References}

1. Paladugu R, Schein M, Gardezi S, et al. One hundred citation classics in general surgical journals. World J Surg. 2002;26(9):1099-105.

2. Garfield E. Citation analysis as a tool in journal evaluation. Science. 1972;178(4060):471-9.

3. Garfield E. To cite or not to cite - note of annoyance. Curr Contents. 1977;35:5-8.

4. Garfield E. 100 citation classics from the Journal of the American Medical Association. JAMA. 1987;257(1):52-9.

5. Lefaivre KA, Shadgan B, O'Brien PJ. 100 most cited articles in orthopaedic surgery. Clin Orthop Relat Res. 2011;469(5):1487-97.
6. Garfield E. Random thoughts on citationology. Its theory and practice - comments on theories of citation? Scientometrics. 1998;43(1): 69-76.

7. Buchwald H. Metabolic surgery: a brief history and perspective. Surg Obes Relat Dis. 2010;6(2):221-2.

8. Bhandari M, Swiontkowski MF, Einhorn TA, et al. Interobserver agreement in the application of levels of evidence to scientific papers in The American Volume of The Journal of Bone and Joint 172 Surgery. J Bone Joint Surg Am. 2004;86A(8):1717-20.

9. Puzziferri N, Austrheim-Smith IT, Wolfe BM, et al. Three-year follow-up of a prospective randomized trial comparing laparoscopic versus open gastric bypass. Ann Surg. 2006;243(2):181-8.

10. Himpens J, Dobbeleir J, Peeters G. Long-term results of laparoscopic sleeve gastrectomy for obesity. Ann Surg. 2010;252(2):319-24.

11. Mattar SG, Velcu LM, Rabinovitz M, et al. Surgically-induced weight loss significantly improves nonalcoholic fatty liver disease and the metabolic syndrome. Ann Surg. 2005;242(4):610-7. discussion 618-20.

12. Sjöström L, Narbro K, Sjöström CD, et al. Effects of bariatric surgery on mortality in Swedish obese subjects. N Engl J Med. 2007;357(8) 741-52.

13. Baker MT. The history and evolution of bariatric surgical procedures. Surg Clin North Am. 2011;91(6):1181-201.

14. Tsai YL, Lee CC, Chen SC, et al. Top-cited articles in emergency medicine. Am J Emerg Med. 2006;24(6):647-54.

15. Hennessey K, Afshar K, Macneily AE. The top 100 cited articles in urology. Can Urol Assoc J. 2009;3(4):293-302.

16. Rosenberg AL, Tripathi RS, Blum J. The most influential articles in critical care medicine. J Crit Care. 2010;25(1):157-70.

17. Link AM. US and non-US submissions: an analysis of reviewer bias. JAMA. 1998;280(3):246-7.

18. Tao T, Zhao X, Lou J, et al. The top cited clinical research articles on sepsis: a bibliometric analysis. Crit Care. 2012;16(3):R110.

19. Fendrich V, Rothmund M. Surgical research in Germany - an international comparison. Chirurg. 2010;81(4):328-33.

20. Campbell FM. National bias: a comparison of citation practices by health professionals. Bull Med Libr Assoc. 1990;78(4):376-82.

21. Garfield E. The history and meaning of the journal impact factor. JAMA. 2006;295(1):90-3.

22. Namdari S, Baldwin K, Kovatch K, et al. Fifty most cited articles in orthopedic shoulder surgery. J Shoulder Elbow Surg. 2012;21(12): 1796-802.

23. Murray MR, Wang T, Schroeder GD, et al. The 100 most cited spine articles. Eur Spine J. 2012;21(10):2059-69.

24. Baldwin KD, Kovatch K, Namdari S, et al. The 50 most cited articles in pediatric orthopedic surgery. J Pediatr Orthop B. 2012;21(5):463-8.

25. Cassar Gheiti AJ, Downey RE, Byrne DP, et al. The 25 most cited articles in arthroscopic orthopedic surgery. Arthroscopy. 2012;28(4): 548-64.

26. Cao F, Li J, Li A, et al. Citation classics in acute pancreatitis. Pancreatology. 2012;12(4):325-30.

27. Ahmad SS, Evangelopoulos DS, Abbasian M, et al. The hundred most-cited publications in orthopaedic knee research. J Bone Joint Surg Am. 2014;96(22):e190. 